\title{
On the Cultivation of Oral English Communicative Competence in Teaching
}

\author{
Yaming $\operatorname{Jin}^{1}$ \\ ${ }^{1}$ School of Foreign Languages, Henan University of Technology, China \\ Correspondence: Yaming Jin, School of Foreign Languages, Henan University of Technology, Lian Hua Street, \\ High Tec Zone, Zhengzhou 450001, China. E-mail: jinyaming2009@tom.com
}

Received: February 12, 2012 Accepted: March 19, $2012 \quad$ Published: June 1, 2012

doi:10.5539/ijel.v2n3p59

URL: http://dx.doi.org/10.5539/ijel.v2n3p59

\begin{abstract}
To develop students' communicative competence is the objective of English teaching. But in the four basic skills, speaking is usually the poorest for English learners in China. After so many years of English learning, Chinese students are often found to hardly communicate with others in English. Obviously there is something wrong with the old traditional methods of oral English teaching. In order to improve Chinese learners' oral communicative competence, some innovative ways in this paper are suggested for English teachers to create a welcoming English atomosphere and a lot of activities are rendered for teachers to encourage students to practice English both in and after class.
\end{abstract}

Keywords: oral English communicative competence, environment, development

\section{Introduction}

English learning is very essential and compulsory in China's current education. It will last at least thirteen years if a Chinese student accomplishes the nine-year compulsory education and four-year higher education not to mention the pre-school education and further study. Since English learning is so time-consuming and energy-consuming, have we Chinese achieved the desired result about English learning? The answer is, to our dismay, "NO". After so many years of English learning, Chinese students are often found to hardly communicate with others in English and they feel dissatisfied with their English despite the fact that they can read or write. English, a tool for communication for most people, loses its value and significance. Obviously there is something wrong with the old traditional methods of oral English teaching. Traditional emphasis on gaining language knowledge through recitation and reading is bound to be gradually replaced by a more integrated approach to English writing, listening, reading and speaking. An official of China's Ministry of Education said language teaching in China in the 21st century should train personnel to be competent enough to use English and communicate with the outside world. "Communicative competence" defined as "the intuitive mastery that the native speaker possesses to use and interpret language appropriately in the process of interaction and in relation to social context” (Hymes 30), a widely-cited concept, should be accepted and emphasized in language pedagogy in China. How to own this competence as to when to speak, when not, and what to talk about with whom, when, where, in what manner is a question which deserves the attention of every English teacher. Jane Villis (1981) once said that the best way to learn English is to go to Britain or America where you can hear people use the language. Illustrating the key importance of environment in English learning, this simple sentence discloses the biggest problem of the current English teaching in China: poor English speaking environment+lack of speaking opportunities. Actually many teaching methods have repeatedly emphasized the importance of target language environment in teaching. The direct method requires more use of target language in instruction. The audiolingual method calls for the creation of target language environment. Language teachers should provide students with a native speaker mode. The silent way holds that teachers should be active in building up classroom situation while students should do most of talking and interaction among themselves. The natural approach concentrates on active demonstrations to convey meaning by associating words and phrases with objects and actions. In the communicative approach, students work with authentic materials in small groups on communication activities during which they receive practice in negotiating meaning. Those representative methods all attest to the fact that whatever focuses or features different teaching methods might have, there is always something invariable: the creation of English learning environment and plentiful activities for teaching and learning. 


\section{The Creation of a Harmonious Communicative Class Climate}

Classroom climate is important because it creates an environment that encourages both achievement and motivation. A positive climate encourages students and allows them to take intellectual risks without fear of criticism for making mistakes. A positive climate helps to reduce students' anxiety and exercise their autonomy freely in the classroom. In a positive climate, students are treated as competent individuals capable of learning and understanding the need to learn. Expectations for both performance and success are high. Students understand the requirements of learning tasks and perceive them as challenging jobs. They believe that the teacher is genuinely committed to their learning and is sensitive to their personal needs. With strong motivation and autonomy, their communicative competence in English increases dramatically. Generally the building of positive class climate relies on the physical environment of classroom and mental world of students and teacher's personality and teaching skills.

\subsection{The Importance of Physical Environment of Classroom and Mental World of Students}

The following descriptions in students' oral presentation at school seems to have far-reaching implications concerning what a language teacher could do to create an environment where students can comfortably speak up: "I am not good at talking. I wouldn't take this course if the classroom had rigid rows of desks and the teacher had us to stand in front near the podium to be seen by others. I feel so scared at the thought of such a course"; "I dislike competition in class. It makes me more and more nervous. I feel my mind is in complete confusion when I feel nervous. But I still want to be number one. ” If we are careful teachers, we may feel that so many of our students own this feeling or that. What the first student is saying is that being exposed to others is a threat, and that the teacher has the power to force learners into such threatening situations. Some teachers have realized the importance of physical environment of classroom for instance the arrangement of chairs in a circle instead of rows may facilitate participation and games or plays may create a comfortable classroom atmosphere. In addition, flowers, nice pictures, colors, music, these all help your learners to open up instantly to their amazing abilities. What the second student is saying is that they do not feel comfortable in competition with one another and that they are at the age of being sensitive and 'vulnerable' in competition. They claim that if teachers get students intentionally involved in the competition for 'good' or 'effective', they will be under great pressure. Even though competition in classroom is said to be able to motivate students to study harder, it might bring about language anxiety which dominates the mental world of students who are less competitive in speaking. They will feel greatly frustrated in self-esteem and self-confidence if they do not compete well. Thus taking the mental world of students into consideration, a co-operative classroom atmosphere is more welcome than a competitive one. For example, if necessary, students can be put in different groups to conduct cooperative activities, which can build greater learner confidence and self-esteem than is less likely in a competitive environment, where self-validation is dependent upon a continuing need to demonstrate success.

\subsection{The Influence of Teachers' Personality and Rich Teaching Skills}

A teacher's personality and rich teaching skills play an essential role in building a harmonious learning atmosphere. A good English teacher might be active and outgoing or peaceful and introvert. No survey has disclosed age, sex and personality itself have more advantages in becoming a good English teacher. The key of being an affectionate and respectable teacher is sincerity, consideration and enthusiasm. Mahatma Ghandi once said: "Power is of two kinds. One is obtained by the fear of punishment and the other by acts of love. Power based on love is a thousand times more effective and permanent than the one derived from fear of punishment." In children's eyes, a teacher owns undoubtedly this noble power to judge, to evaluate, to praise or to reprimand. How to evade the power rendered by the fear of punishment and manipulate the power based on love to achieve the desired learning result is a question which is easier said than done. In general, good teachers usually keep to the following practice:

1). Be firm in a gentle way and give students praise whenever they are doing anything close to a good job.

2). Be sincere to and confident in students, find their achievements to encourage them. Never get frustrated, angry and impatient.

3). Be a nice, sensitive and approachable person at all times. Never treat students differently or put them on the spot.

4). Treat them with kindness and respect, smile a lot and value their opinions. Never embarrass anyone with a laugh.

This practice is done smoothly and easily by those teachers who consider their instinction to love their students faithfully and observe every student in his force-field and have everyone in his control. Of course love is far 
from enough. Good and amazing teachers should adopt different teaching methods to cater to the needs of different students. Some learners are visual and learn through their eyes by seeing. Some are audial and learn through their ears and mouths by hearing and speaking. Some are kinesthetic and learn through touch and moves. If teaching is satisfying different types of students, students are willing to learn. Teachers should organize various interesting activities in teaching to entertain as well as to teach, to solve the difficult point and emphasize the important point. Teachers can adopt games, singing and guessing activities to lead into the new lesson; make use of simple drawing, recorder and multimedia to aid the teaching; adopt situational teaching, debate and argument to make everyone involved in the process. These teaching methods will make students interested in speaking by means of which under the supervision of loving and caring teachers, students are more inclined to speak English freely and to the limits of their ability.

\section{Typical Activities to Improve English Communicative Competence}

\subsection{Ask and Answer Dialogue}

Asking and answering orally is the most ancient method in foreign language teaching. So far it still has strong vitality because asking and answering is used most frequently in daily life. The dialogue can be made between the teacher and the students, or among the students themselves. In contemporary student-centered oral English teaching, we advocate that students ask and students answer, even students ask and the teacher answers so as to motivate students to speak actively. The dialogue can be made about the text we have learnt. In fact, such kind of questions is often designed after each text for students to practice. Also, the students themselves can give questions about text, and then let others answer. If answerers have difficulty in answering questions, questioners can give suggestions.

\subsection{Situational Dialogue}

Situational dialogue is a dialogue of role-play in which students are required to make dialogues according to given situations to reach the final goal of improving their oral communicative competence. In this practice, students play various roles and start conversations with others by imagining that they are in different situations such as in the restaurant, at the station, at the post office, in the medical clinic and in the shop.

In practicing situational dialogue, students are the main participants while the teacher is an organizer, an investigator, and an encourager. For some mistakes in dialogues, the teacher shouldn't interrupt their speaking to correct them in case their enthusiasms were damaged. A better way is to write down the mistakes, and choose some typical ones to explain and practice after their dialogue. Situational dialogue can be conducted in pairs or in groups. Students not only show their speaking ability but also fully display their acting ability.

\subsection{Communicative Dialogue}

Communicative dialogue is a dialogue of random practice according to the real situation in our study or life. In other words, it is the impromptu dialogue when students are not well-prepared. This practice can improve students' speaking fluency and accuracy. It also can cultivate the good habit of thinking and speaking in English. For instance, after learning the text "Travel”, students are arranged to practice the impromptu dialogue in pairs or groups with the sentences and phrases they have learnt in text according to their own traveling experiences so as to improve their oral communicative competence.

\subsection{Discussion and Debate}

Discussion is a kind of group work, which is essential to English teaching and can increase language practice opportunities, improve the quality of students' talking, help to individualize instruction and motivate learners to learn. Discussions can effectively include the exchange of various opinions though sometimes opinions may be appropriate or not, especially when the objective of a task is to deal more with "fact".

Taking teaching a text for example, communicative discussions may run through the whole teaching process from pre-reading to post-reading. Before reading the text, a discussion should be held to let students say something they know about the theme or hero of the text. After two minutes, the teacher can ask two group leaders to tell the class what they know about the theme or the character. The purpose of this discussion is just to activate the students' background knowledge and arouse their interest in the lesson. After the process of fast reading and intensive reading, the students have grasped the main idea and some information about the text. But do they know the writer's purpose of writing and implication? So it is necessary to come to the teaching step of re-reading. During this time, the teacher puts forward two or more critical questions about the writer's implication or writing purpose and then let the students have a second discussion. In another three minutes, several group leaders are called to report their answers to the whole class. At this time, the teacher is an evaluator. He should evaluate if their understanding is right or wrong. 
Since students have a deep understanding of the text, the teacher should grasp the chance to develop students' creative thinking. Some creative questions can be raised to let them have a third discussion. In this process, students are divided into two sides. Each side chooses some debaters. They will speak out their viewpoints according to their own understanding. After the debate, the teacher should evaluate their opinions objectively and make a proper summary of the issue.

In this kind of reading lessons, there are more opportunities for students to speak out since three communicative activities of discussion are arranged. Their anxieties over making mistakes will be diminishing and their shyness will be gone by and by. Certainly their oral communicative competence will be cultivated.

\subsection{Retelling}

Retelling is a common activity adopted by teachers in a reading lesson in which students are required to tell the story in their own words after completely understanding the text. It is an important form of oral practice through which students' ability to apply the language points comprehensively is greatly improved. Students can retell the text they have learnt with different persons, voices or tenses or the teacher can write down the key words on the blackboard according to the thread of the text to guide students to retell. By this means, students can memorize the text quickly and easily, and avoid learning by rote. Also, the teacher can draw simple pictures, which are concise and vivid, to guide students to retell the text. It combines language with pictures to build a language environment to help students understand and learn the knowledge by heart. So the students' oral communicative competence can be improved gradually.

\subsection{Story Telling}

Ask students to read some stories with right intonation, pronunciation, gesture and expressions in their spare time. This will motivate students to be enthusiastic to speak standard and fluent English. First, the students who are interested in this activity can choose materials to prepare. Next, the teacher guides them to speak accurately with better pronunciation and intonation. Then, ask some students to recite the story in class. At last, select the best story teller to reward. The teacher also can ask students to invent impromptu stories by providing them with situations and characters. Students can get lots of fun from it.

\subsection{Free Talk}

Free talk is an effective oral practice in which teacher help students choose those topics that have something to do with their interest and experience and those subjects without definite answer such as holidays, nature, ads, environment and pollution. On some occasions students are completely free to choose the topics that they want to talk about. More often they like to talk about such topics as movie stars, songs, music, magazines, sports and travel. In this way, students not only improve their speaking abilities but also broaden their minds and enlarge their vocabulary.

\subsection{Short Play and Speech Contest}

Conducting these activities like short play and speech contest will give full play to students' oral English competence. In order to make more students participate, first we can hold the contest in class; select the best actors to participate in the grade contest, and then the school contest. Even students can be judges to give marks to the speakers or actors. Through this way, students will have great enthusiasm to take part in these activities, read the extracurricular books, search for data on the Internet, write the manuscript and rehearse the play. These activities provide students with more chances to show their speaking and acting abilities. Students often enjoy themselves a lot. Also, their oral communicative competence is raised in this process.

\subsection{English Corner}

Organize an English corner at school and let students talk freely with those who are interested in learning English. English corner is a platform where students no longer feel shy, where they can choose interesting topics to communicate with different people and where they can freely voice their own opinions. This is a quite practical way to improve oral communicative competence effectively.

\section{Conclusion}

The goal of foreign language teaching is to develop communicative competence. The ways to arouse students' interest and oral activities suggested in class or after class in this thesis are easy to operate for every English teacher who is determined to be a caring and responsible teacher. So it is possible and practical to popularize the activities in different stages of English teaching and learning in China. Through various oral activities, students become controllers of their study and gain much more chances to practice oral English. As time goes by, shyness and nervousness are replaced by enthusiasm and interest and they will become more and more confident about 
their English. All in all, speaking as one of the four basic skills can be mastered only through practice. Practice makes perfect.

\section{References}

Brumfit, C. J., \& Johnson, K. (2000). The Communicative Approach to Language Teaching. Shanghai: Shanghai Foreign Language Education Press.

Brown, H. D. (2001). Teaching by Principles: An Interactive Approach to Language Pedagogy. Beijing: Foreign Language Teaching and Research Press.

Bartlett, L., Richards, C., \& J., Nunan, D. (1990). Teacher Development Through Reflective Teaching. Second Language Teacher Education. Cambridge: Cambridge University Press.

Ellis, Rod. (2000). Understanding Second Language Acquisition. Shanghai: Shanghai Foreign Language Education Press.

Genesee, F. (1976). Language Learning. London: Academic press.

Hymes, D. (1971). Language Acquisition: Models and Methods. London: Academic Press.

Johnson, Karen, E. (2000). Understanding Communication in Second Language Classroom. Beijing: Foreign Language Teaching and Research Press.

Villis, Jane. (1981). Teaching English Trough English. Hongkong: Longman House.

Wang, Cairen. (1996). On the Communicative Theory of English Teaching. Guilin: Guangxi Educational Publishing House.

Zuo, Huanqi. (2001). The Future of English Teaching. Shanghai: Huadong Normal University Publishing House. 